\title{
Use of intracage ventilation systems in animal facilities
}

\author{
Uso de sistemas de ventilação microambiental aplicada a biotérios \\ André Silva Carissimi ${ }^{1}$, Maria Araújo Teixeira ${ }^{2}$, Luziane do Carmo \\ Andrade Guinski Chaguri ${ }^{3}$ \& José Luiz Bernardino Merusse ${ }^{4}$
}

\begin{abstract}
The breeding and housing of animal species in intensive production systems require a higher control of the environmental variables inside the facilities, on behalf of an atmosphere that maintains a sanitary status and also promotes the well-being of the animals. The husbandry of laboratory animals is one of those productive systems in which the environmental control should be quite rigorous due to the maintenance of defined animals such as specific pathogen-free and gnotobiotics. For a long period, the control of ventilation and environmental factors of conventional animal facilities was achieved by using thermodynamic principles used for human comfort. However, in the last decades, new approaches to solve the environmental problem in animal rooms were studied, and the ventilation systems developed with base in forced convection of the air were the ones that presented the best results until the present time. Thus, this review presents, in an historical perspective, the evolution of alternative devices for caging of laboratory animals and their effects on the animals.
\end{abstract}

Key words: animal facilities, housing, caging, ventilation, rodent, environment.

\section{RESUMO}

A criação e manutenção de espécies animais em sistemas intensivos de produção requerem um maior controle das variáveis ambientais dentro das instalações, em prol de um ambiente que mantenha um padrão de sanidade na colônia e promova o bem-estar dos animais. A produção de espécies de animais de laboratório é um desses sistemas produtivos em que o controle do ambiente deve ser bastante rigoroso devido a manutenção de linhagens sanitariamente definidas como animais livres de patógenos específicos ou gnotobióticos. Por um longo período, os princípios de ambiência utilizados em biotérios não passavam de uma mera aplicação dos princípios termodinâmicos para conforto humano. Entretanto, nas últimas décadas, novas abordagens para o equacionamento do problema ambiental em salas de animais foram estudadas, sendo que os sistemas de ventilação desenvolvidos com base no princípio da convecção forçada do ar foram os que apresentam os melhores resultados até o presente momento. Dessa forma, esta revisão apresenta, em uma perspectiva histórica, a evolução dessa alternativa para alojamento de animais de laboratório além de abordar os avanços na área de ambiência em biotérios e seus efeitos sobre os animais.

Descritores: Biotério, alojamento, ambiência, ventilação, roedor, ambiente. 


\section{INTRODUCTION}

\section{INTRACAGE VENTILATION SYSTEMS}

\section{Antecedents}

\section{Effects on animal health}

\section{Microenvironmental Ventilation Systems (VMA systems)}

\section{CONCLUSION}

\section{INTRODUCTION}

Since last century, the animal experimentation has been contributing to the evolution of the biological sciences and the study of new theories based on in vivo assays with animal models. Thus, with the development of the scientific research there was the requirement to supply and to house animals with the quality demanded by the researchers. In this way, the animals were standardized in the genetic and sanitary status, appearing thus new strains and the concern with the sanitary status of the animals. At the same time, there was the requirement of standardization of the environment where the animals are bred and maintained; therefore, it is known that certain experimental results are susceptible to alterations for variations in the environmental factors [10].

For a long time, it was considered that the control of the environmental conditions in animal rooms (macroenvironment) it would be enough for the control of the environmental variables inside of the animal cages (microenvironment). In this manner, the concepts recommended for human comfort were applied to animal rooms [46]. These systems are known as VGD system (General Diluting Ventilation system) and although, unquestionably efficient for the man, the use of VGD settings in animal facilities demonstrated to be inadequate.

The microenvironment possesses environmental characteristics different to those of the macroenvironment, mainly in function of the mechanisms of thermal changes and liberation of gases by the animals that are processed inside the cage $[1,2]$. As a result of the several metabolic processes, products are detected as water vapor, carbon dioxide $\left(\mathrm{CO}_{2}\right)$, particles in suspension and ammonia $\left(\mathrm{NH}_{3}\right)$, being necessary the removal of those pollutants on behalf of the maintenance of favorable conditions for breeding of laboratory animals. Besides the removal of the polluted air, it is necessary the supply of new, clean air in adequate amount and quality $[6,30,48,60]$.

The process of air exhaustion or supply, conditioned or not, by natural or mechanical means, from/ for a closed enclosure, with the purpose of removing pollutants or to maintain comfort conditions is denominated ventilation [41]. The ventilation is divided in two great principles: the ventilation for process (VLE) and the ventilation for comfort (VGD). The VLE consists, generally, in removing the industrial pollutants, while VGD is based on temperature control and reduction of the carbon dioxide tension $\left(\mathrm{CO}_{2}\right)$ in the areas destined to the human use $[3,61]$.

The application of VGD in animal facilities began in the 1940's, with the use of a system in which the ventilation occurred through a mixture of external and internal air, recirculated after previous filtration [46]. For many years, the VGD system was used in animal facilities. The VGD system should maintain the temperature as uniform as possible, the relative humidity around $50 \%$, with an air renewal of 18 changes per hour, without recirculation, and insufflation by the ceiling and exhaustion at the floor level. In spite of the limitations of VGD, the animal facilities projected with it undoubtedly present better quality than facilities without any ventilation devices.

Nevertheless, the use of VGD system for laboratory animals presents several limitations. The most important is that even increasing a maximum ventilation rate for a room it does not yield the same effect inside the cages, its efficiency is decreased and the microenvironment presents the challenges of high temperature, humidity and pollutants concentration due to decreased air speed inside the cages $[47,79]$.

The pollutants formed inside the cages reach the macroenvironment in virtue of the airflow distribuition pattern. Some works describe a significant difference of the air speed among the airflow directions existent inside and outside the boxes, favoring 
the accumulation of substances inside the cages [47, 79]. The airflows are also responsible for the removal of the corporal heat of the animals, because that process occurs mainly through the free convection. The convection is one of the ways of heat transmission, caused by the relative movement of the particles of the fluid, due to the difference of pressure generated by the difference of temperature and consequent difference of density of the air mass $[18,24,25]$. Basically, the cages possess low thermal conductivity because they are manufactured with plastic material (polypropylene and polycarbonate) and, consequently, increase the difference of temperature between micro and macroenvironment, making the temperature higher in the microenvironmet, facilitating naturally the convection process (free convection) $[4,15$, 21,75].

\section{INTRACAGE VENTILATION SYSTEMS}

\section{Antecedents}

A more specific approach for animal facilities has began to be studied, based on the forced convection. The forced convection is the phenomenon due to the intensification of that process produced by the agitation of the air mass, in this case, by fans that promote the passage of an unidirectional airflow inside the boxes [24,26,27,70,74].

In the late 1950's, it was built the first cage using the forced convection principle in order to maintain animals free from contaminations. That system had cylindrical format and it was elaborated with stainless steel covered by a filtering membrane that assured the health of the animals [33].

In 1970, the first step of a new technology for animal facilities ventilation was proposed, consisting of a rack that was composed by a plenum chamber responsible by promoting an airflow upon the cages using the same air of the room [35]. A similar device was capable to prevent the contamination of gnotobiotic animals maintained in cages without filter tops [73]. The first registration of a cabinet for animals with equipments for thermal control of the air occurred in 1972 for the housing of specific pathogen-free chickens [75].

The reduction in the bacterial counting inside a rack for maintenance of rats was obtained with use of a vertical descendant curtain of air at $0.9 \mathrm{~m} / \mathrm{s}$ $[42,73]$. The low counting of bacterial colonies were also verified inside a cabinet for maintenance of guinea pigs, however, unlike the previous, that equipment was the first to operate with internal pressure higher than the external pressure [55].

In 1973, it was described a system in which the air was thrown at the room by the ceiling and removed through openings on the wall, behind the shelves, that coincided with the superior level of the cages. In such system, the exhausted air was really removed from the room after contact with the boxes, decreasing the possibility of return to the room $[1,20$, 72,77]. The same system served as a model for the development of another one where the exhaustion was performed by a plenum chamber of negative pressure ("full-wall") whose structure provided also the separation of the animal rooms [25]. The use of a chamber ventilated by a vertical descendant airflow demonstrated a directly proportional relationship between the filtered air speed and the maintenance of the sanitary status of axenic mice $[43,57]$.

The equipments developed until then promoted the change of air of the interior of the cages through diffusion at the superior level of the cage covers [44]. However, when the use of filter diffused for control of infections in animal facilities was spread, the differences between macro and microenvironment increased. The evaluation of three types of filters for box covers, taking in account environmental variables, has demonstrated that cages with polycarbonate filters tops presented higher carbon dioxide concentrations when compared to those with top filters constituted of polyester $[17,37]$. The relative humidity of the air was higher in the boxes equipped with filters tops, independently of the type of used filter. However, significant differences were not observed in the temperature and ammonia concentrations of the microenvironment, for all types of used filters. However, these results were significantly higher than those observed in the macroenvironment $[17,38]$.

The alternative to reduce the levels of pollutant inside the cages was the adoption of a system of individual ventilation for each cage (called intracage ventilation system) as previously proposed [33].

\section{Effects on Animal Health}

Aiming the improvement of the microenvironment, ventilation systems with positive pressure inside the cages were developed and they demonstrated ability to control more efficiently temperature, 
humidity relative of the air, levels of ammonia, carbon dioxide and allergens [5,22,23,29,31,32,34,38, $39,56,58,76]$

The ventilation systems with positive pressure (PIV systems - Positive Intracage Ventilation) described until now are characterized by the insufflation of conditioned air inside the cages with air speed ranging from $0.09 \mathrm{~m} / \mathrm{s}$ to $0.5 \mathrm{~m} / \mathrm{s}$ [4,34,71] and exhaustion through a plenum chamber of negative pressure. With speed of air of $0.09 \mathrm{~m} / \mathrm{s}$, the levels of ammonia remained around $20 \mathrm{ppm}$ in rat cages (biomass of 500 grams by box) along a period of 13 days without bedding changes in a PIV system [78]. In a subsequent study, it was observed that the same speed was enough to control the $\mathrm{CO}_{2}$ and oxygen $\left(\mathrm{O}_{2}\right)$ concentrations inside the rat boxes [28].

A commercially PIV system available was analyzed and demonstrated to attend the exigency of England's "Home Office Code of Practice", being capable to maintain the animals free from contaminants and other stressful factors, making possible a less variable environment and, therefore, minimizing possible interferences on the experiments, besides protecting the researcher [16].

The formation of thirteen pollutants, including ammonia and $\mathrm{CO}_{2}$, in eight different bedding types was measured in PIV cages with air speed of $0.3 \mathrm{~m} / \mathrm{s}$. The corn cob bedding was the one that favored less the production of ammonia, increasing the interval of bedding changes frequency and thus reducing the stress of the animals caused by handling the boxes [36,49,51]

In three PIV systems the levels of pollutants were compared with those found in conventional boxes. As results, significant differences in the temperature and in the levels of $\mathrm{CO}_{2}$ were not observed, but ammonia levels and relative humidity of the air were higher in the conventional cages when compared to the three types of PIV cages. As for the intensity and the frequency of the sounds, the three PIV systems produced more sounds, up to $250 \mathrm{Hertz}(\mathrm{Hz})$, than the macroenvironment. However, those systems generated less high frequency sounds than the macroenvironment that are less tolerated by the animals. Such results indicate that the noises produced by the PIV systems in the range of frequency measured $(31.5 \mathrm{~Hz}$ up to $16000 \mathrm{~Hz}$ ), probably exert little effect on the animals [50].

Although an air renewal rate in the macroenvironment about five air changes per hour is known to be enough to control levels of ammonia and $\mathrm{CO}_{2}$ inside the boxes [52,53], individually ventilated caging systems from several manufacturers are available with a variety of air renew rates. Thus, optimal ventilation rates for PIV systems have not been determined yet. Rates differ among systems and they may vary according to the cage design as well. In spite of different configurations, it is not known yet which is the best distribution of air inside the cage, the most appropriate speed, or which air renewal rate per hour is more appropriate to provide a better housing for the animals [71]. Although increased airflows may have advantage in reducing pollutants such as ammonia, carbon dioxide and humidity values, they may have potentially detrimental effects upon the animals (chilling). Those data can establish a new concept regarding to cage density and conditions in these PIV systems [53].

The temperature variation, relative humidity of the air, levels of ammonia and $\mathrm{CO}_{2}$ in function of the bedding change frequency were studied in PIV cages with mice. With a ventilation rate of 30 air changes/hour, cages with four adult mice reached ammonia levels of $10 \mathrm{ppm}$ in the seventh day without bedding changes. However, a box containing a couple and their offspring need 100 air changes/hour to maintain the same levels of ammonia in the same period $[51,58]$.

The limiting factor of PIV systems commercially available is the expensive acquisition and operation cost, since air insufflated inside of the system must be previously conditioned [16].

\section{Microenvironmental Ventilation Systems (VMA systems)}

With base on the same process, an equipment was developed using just ventilation inside the boxes of the animals, with exhaustion of the air outside of the room (system VMA) [45,54]. Such system operated through plenum chambers of insufflation and of exhaustion dispensing secondary ducts of connection between the boxes and main ducts, as in the systems previously described and neither needed the air conditioning $[7,11,12,14,62,68]$.

The advantages of this system are not limited to economical costs of operation, but mainly it possesses sanitary advantages since the animals evaluated until the moment showed increased productivity, less respiratory lesions and rheological proper- 
ties similar to those animals maintained in systems with air conditioning [40,63-66]. Regarding to the reproductive performance, both mice and rats maintained in the VMA system presented reproductive indices higher than the animals maintained in a conventional ventilation system $[8,13,69]$. Swiss mice maintained in VMA system were accompanied during four gestations and they presented shorter intervals between parturitions starting from the second delivery when compared with animals housed in the conventional system. The number of born and weaned animals was also higher from the second litter in the breeders maintained in the VMA system [69]. Similar trial using Wistar rats demonstrated that couples housed under the VMA system, with air speed between 0.03 and $0.80 \mathrm{~m} / \mathrm{s}$, did not present alteration in fertility or life span indices. However, the offsprings were significantly larger and more uniform at the birth and at the weaning there was less mortality of neonates [13].

The reduction of the levels of ammonia was also observed in all air speed ranges used in the VMA system, with the consequent reduction of respiratory lesions induced by the concentration of ammonia in the atmosphere [7,59]. Histopathological analyses have been demonstrating to smaller incidences of lung lesions in animals maintained in the system [59], attributed probably to the low ammonia concentrations inside the cages in VMA system by increasing evaporation of bedding humidity provided by air flow $[9,67]$. As result, the offsprings of the mice and rats maintained in the VMA system presented smaller incidences of lung lesions in a broad range of air speed, especially those settled between 0.19 and $0.80 \mathrm{~m} / \mathrm{s}[13$, 69]. Similar data were obtained in adult Wistar rats housed for 180 days in VMA system with different intervals of bedding changes [8]. The group maintained with bedding change frequency of 7 days presented lower incidece of lung lesions (congestion, peribronchitis and interstitial pneumonia) when compared to all bedding change intervals group [8]. The epithelial integrity was also studied by transepithelial membrane potential (DDP) on the nostrils, epiglottis and trachea of rats kept under VMA systems and submitted to different intervals of bedding change. DDP evaluation presented significant differences in the results form trachea and epiglottis in the group housed with bedding changes of 7 days when compared to the others groups. This group showed minor lesions, presumably by lower ammonia concentrations in caging conditions [8]. Thus, the use of the VMA system is may possibly increase the bedding change frequency, reducing the operational cost of the animal facilities without prejudice for the sanitary quality of the animals kept in animal facilities [8].

The promotion of an appropriate environmental condition is also proven by the studies of rheological properties of the mucus of animals maintained in VMA system. In spite of being submitted to speeds of air superior to the animals maintained in conventional system, parameters as in vitro mucus transportability, contact angle and rigidity of the mucus do not differ from material originated from animals maintained in systems with air conditioning $[19,65]$.

\section{CONCLUSION}

Although there are different conceptions among the systems that use unidirectional airflow inside the cages (PIV systems and VMA system), the results obtained up to now demonstrate that a technology type provides an improvement in the quality of the air, making possible the increase of the interval of bedding change without any prejudice for the sanitary status of the animals. The VMA system differs of the PIV system for the fact of not using the conditioning of air, becoming more accessible to the researcher and reducing the operational cost at the same time that the animals maintained in that system possess similar characteristics to the animals maintained in PIV systems [8].

Although the accomplished studies approach just outbred rats and mice, it is important to evaluate the use of the VMA system for other strains and species of laboratory animals.

\section{REFERENCES}

1 Allander C. \& Abel E. 1973. Some aspects of the differences of air conditions inside a cage for small laboratory animals and its surroundings. Zeitschrift fur Versuchstierkunde. 15: 20-34.

2 Alschuler J.H. 1963. Air treatment for research animal housing. Laboratory Animal Care. 13: 321-331.

3 ASHRAE-American Association of Heat, Refrigerating and Airconditioning Engeeniring. 1997. Reliable, efficient systems for biomedical research facility. ASHRAE Journal. 39: 52-54. 
4 Besch E.L. 1985. Definition of laboratory animal environmental conditions. In: Moberg G.P. (Ed). Animal Stress. Bethesda: American Physiological Society, pp.297-315.

5 Broderson J.R., Lindsey J.R. \& Crawford J.E. 1976. The role of environmental ammonia in respiratory mycoplasmosis of rats. American Journal of Pathology. 85: 115-127.

6 Canadian Council on Animal Care. 1998. Guide to the care and use of experimental animals. Ontário:CCAC, pp.15-22.

7 Carissimi A.S., Chaguri L.C.A.A., Teixeira M.A., Mori C.M.C., Guimarães-Santana E.T., Saldiva P.H.N., Souza N.L. \& Merusse J.L.B. 2000. Effects of two ventilation system and bedding change frequency on cage environmental factors in rats (Rattus norvegicus). Animal Technology. 51: 161-170.

8 Carissimi A.S., Chaguri L.C.A.A., Teixeira M.A., Mori C.M.C., Souza N.L. \& Merusse J.L.B. 2000. Aumento do desempenho reprodutivo em ratos (Rattus norvegicus) pela utilização de sistemas de ventilação ambiental [resumo 195]. In: XXI Congresso Brasileiro de Clínicos Veterinários de Pequenos Animais (Rio de Janeiro, Brasil). Revista Brasileira de Ciência Veterinária 7: 195.

9 Carissimi A.S., Chaguri L.C.A.A., Teixeira M.A., Souza N.L., Nahas G. \& Merusse J.L.B. 1996. Determinação do teor de umidade em maravalha servida em Biotérios de ratos. In: Anais da XX Semana Científica do Departamento de Patologia - FMVZ-USP (São Paulo, Brasil). p12.

10 Cassel G.H., Lindsey J.R. \& Davis J.K. 1981. Respiratory and Genital Mycoplasmosis of laboratory rodents: implications for biomedical research. Israel Journal of Medical Science. 17: 548-554.

11 Chaguri L.C.A.G. 1997. Ventilação microambiental para Biotérios: estudo experimental em ratos (Rattus norvegicus). 83f. São Paulo, SP. Dissertação (Mestrado em Patologia Experimental e Comparada) - Programa de Pós-graduação em Patologia Experimental e Comparada, Universidade de São Paulo.

12 Chaguri L.C.A.G., Carissimi A.S., Mori C.M.C., Nahas G., Souza N.L. \& Merusse J.L.B. 1997. Sistema de Ventilação Microambiental Para Biotérios: Estudo Experimental Em Ratos (Rattus norvegicus) [Resumo 45]. In: IV Simpósio de Ciências Médicas e Biológicas da UFPR (Curitiba, Brasil). Archives of Veterinary Science. 2: 45.

13 Chaguri L.C.A.G., Souza N.L., Teixeira M.A., Mori C.M.C., Carissimi A.S. \& Merusse J.L.B. 2001. Evaluation of reproductive indices in Rats (Rattus norvegicus) housed under and intracage ventilation system. Contemporary Topics In Laboratory Animal Sciences. 40: 25-30.

14 Chaguri L.C.A.G., Teixeira M.A., Carissimi A.S., Souza N.L., Nahas G. \& Merusse J.L.B. 1996. Ventilação Microambiental Para Biotérios: Estudo Estimativo d a carga térmica devido a camundongos (Mus musculus) [Resumo 31.022]. In: Anais da XI Reunião Anual da Federação das Sociedades de Biologia Experimental (Caxambú, Brasil). p.320.

15 Clough G. 1976. The immediate environment of the laboratory animal. In: Mcsheehy T. (Ed). Control of the animal house environment. Londres: Laboratory Animals, pp.77-94.

16 Clough G., Wallace J., Gamble M.R., Merryweather E.R. \& Bailey E. 1995. A positive, individually ventilated caging system: a local barrier system to protect both animals and personnel. Laboratory Animals. 29: 139-151.

17 Corning B.F. \& Lipman N.S. 1991. A comparison of rodent caging systems based on microenvironmental parameters. Laboratory Animal Science. 41: 498-503.

18 Costa E.C. 1991. Física aplicada à construção: Conforto térmico. 4.ed. São Paulo: Edgard Blücher, 259p.

19 Dalhamn T. 1956. Mucus flow and ciliary activity in the trachea of healthy rats and rats exposed to respiratory irritant gases. Acta Physiologica Scandinavica. 36: 1-161.

20 Egan B.J. \& Butler E.J. 1972. Controlled environment systems for experimental animals. II. A unidirectional air flow tent. Laboratory Animals. 6: 119-125.

21 Eveleigh J.R. 1993. Murine cage density: cage ammonia levels during the reproductive performance of an inbred strain and two outbred stocks of monogamous breeding pairs of mice. Laboratory Animals. 27:156-160.

22 Francis L. 1981. General Hazards. In: Seamer J.H. \& Wood M. (Eds). Safety in the animal house. 2nd edn. Londres: Laboratory Animals, pp.1-10.

23 Gamble M.R. \& Clough G. 1976. Ammonia build-up in animal boxes and its effect on rat tracheal epithelium. Laboratory Animals. 10: 93-104.

24 Gordon C.J. 1993. Temperature Regulation in laboratory rodents. New York: Cambridge University Press, 276p.

25 Gorton R.L. 1975. System design and energy conservation considerations. ASHRAE Transactions. 81: 572-578.

26 Gorton R.L., Woods J.E. \& Besch E.L. 1976. System load characteristics and estimation of annual heat loads for laboratory animal facilities. ASHRAE Transactions. 82: 107-112.

27 Hardy R.N. 1981. Temperatura e vida animal. 2.ed. São Paulo: EDUSP, pp.26-36. 
28 Hasegawa M., Kurabayashi Y., Ishii T., Yoshida K., Uebayashi N., Sato N. \& Kurosawa T. 1997. Intra-cage Air change rate on forced-air-ventilated micro-isolation system - environment within cages: carbon dioxide and oxygen concentration. Experimental Animals. 46: 251-257.

29 Hunskaar S. \& Fosse R.T. 1990. Allergy to laboratory mice and rats: a review of the pathophysiology, epidemiology and clinical aspects. Laboratory Animals. 24: 358-374.

30 Institute for Laboratory Animal Resources - National Research Council (ILAR). 1996. Guide for Care and Use of Laboratory Animals. New York: National Academy Press, 96 p.

31 Jones R.B., Kacergis J.B., Macdonald M.R., Mcknight F.T., Turner W.A., Ohman J.L. \& Paigen B. 1995. The effect of relative humidity on mouse allergen levels in an environmentally controlled mouse room. American Industrial Hygiene Association Journal. 56: 398-401.

32 Keller G.L., Mattingly S.F. \& Knape Jr. F.B. 1983. A forced-air individually ventilated caging system for rodents. Laboratory Animal Science. 33: 580-582.

33 Kraft L.M. 1980. The manufacture, shipping and receiving and quality control of rodent bedding materials. Laboratory Animal Science. 30: 366-376.

34 Kurosawa T., Yoshida K., Okamoto M. \& Tajima M. 1993. Invention of an air forced ventilated micro-isolation cage and rack system - environment within the cages: ventilation, air flow. Experimental Animals. 42: 547-554.

35 Lane-Petter W. 1970. A Ventilation barrier to the spread of infection in laboratory colonies. Laboratory Animals. 4: 125-134.

36 Lindsey J.R. \& Conner M.W. 1978. Influence of cage sanitization frequency on ontracage ammonia concentration and progression of murine respiratory mycoplasmosis in the rat. Zentralblatt für Bakteriologie, Parasitunkunde, Infektions Krankheiten und Hygiene. 241A: 215.

37 Lipman N.S., Corning B.F. \& Coiro Jr. M.A. 1992. The effects of intracage ventilation microenvironmental condition in filter-top cages. Laboratory Animals. 26: 206-210.

38 Lipman N.S., Corning B.F. \& Saifuddin M.D. 1993. Evaluation of isolator caging system for protection of mice against challenge with mouse hepatitis virus. Laboratory Animals. 27: 134-140.

39 Lorusso J.R., Moffat S. \& Ohman Jr. J.L. 1986. Immunological and biochemical properties of the major mouse urinary allergen (Mus m1). Journal of Allergy and Clinical Immunology. 45: 928-937.

40 Macchione M., King M., Lorenzi-Filho G., Guimarães E.T., Zin W.A., Böhm G.M. \& Saldiva P.H.N. 1995. Rheological determinants of mucociliary transport in the nose of the rat. Respiration Physiology. 99: 165-172.

41 Macintyre A.J. 1990. Ventilação Industrial e controle da poluição. Rio de Janeiro: Guanabara Koogan, 104p.

42 McGarrity G.J. \& Coriell L.L. 1973. Mass air flow cabinet for control of airborne infection of laboratory rodents. Applied Microbiology. 26: 167-172.

43 McGarrity G.J. \& Coriell L.L. 1976. Maintenance of axenic mice in open cages in mass air flow. Laboratory Animal Science. 26: 746-750.

44 McSheehy T. 1976. Control of the animal house environment. Londres:Laboratory Animals, $335 \mathrm{p}$.

45 Merusse J.L.B. 1995. Equipamento para criação e manutenção de animais utilizados em experimentação biomédica e respectivo processo de distribuição unidirecional do ar. Revista de Propriedade Industrial n. 1262, fevereiro, p. 28. Patente 9302341-3.

46 Munkelt F.H. 1938. Odor control in animal laboratories. Heating Piping and Air conditioning. 10: 289-291.

47 Murakami H. 1971. Differences between internal and external environments of the mouse cage. Laboratory Animal Science. 21: 680-684.

48 Organizacion Panamericana de la Salud. 1968. Animales de Laboratório. Guia para instalaciones y cuidado de animales de laboratório. Washington: OPAS, $54 \mathrm{p}$.

49 Perkins S.E. \& Lipman N.S. 1995. Characterization and quantification of microenvironmental contaminants in isolator cages with a variety of contact beddings. Contemporary Topics. 34: 93-98.

50 Perkins S.E. \& Lipman N.S. 1996. Evaluation of microenvironmental conditions and noise generation in three individually ventilated rodent caging systems and static isolator cages. Contemporary Topics. 35: 61-65.

51 Potgieter F.J. \& Wilke P.I. 1992. Laboratory Animal Bedding: a review of wood and wood constituents as a possible source of external variables that could influence experimental results. Animal Technology. 43: 65-88.

52 Reeb C.K., Jones R.B., Bearg D.W., Bedigian H., Myers D.D. \& Paigen B. 1998. Microenvironment in ventilated animal cages with differing ventilation rates, mice populations, and frequency of bedding changes. Contemporary Topics. 37: 43-44. 
53 Reeb C.K., Jones R.B., Bearg D.W., Bedigian H. \& Paigen B. 1997. Impact of room ventilation rates on mouse cages ventilation and microenvironment. Contemporary Topics. 36: 74-79.

54 Rossi P.R., Teixeira M.A., Souza N.L. \& Merusse J.B.L. 1994. Obtenção de fluxo unidirecional de ar em sistema de ventilação microambiental (VMA) para Biotérios [Resumo 16]. In: Anais do IV Congresso Brasileiro de Animais de Laboratório (Guarujá, Brasil). p.35.

55 Rylander R. \& Hellström P.A. 1973. Versatile cage for environmental protection housing of research animals. Laboratory Animal Science. 23: 876-879.

56 Schoeb T.R., Davidson M.K. \& Lindsey J.R. 1982. Intracage ammonia promotes growth of Mycoplama pulmonis in the respiratory tract of rats. Infection and Immunity. 38: 212-217.

57 Schoeb T.R., Kervin K.C. \& Lindsey J.R. 1985. Exarcebation of murine respiratory mycoplasmosis in gnotobiotic F344/N rats by sendai virus infection. Veterinary Pathology. 22: 272-282.

58 Serrano L.J. 1971. Carbon dioxide and ammonia in mouse cages: effect of cage covers, population and activity. Laboratory Animal Science. 21: 75-85.

59 Sinhorini I.L., Teixeira M.A., Rossi P.R., Souza N.L. \& Merusse J.B.L. 1994. Redução da incidência de lesões pulmonares em camundongos mantidos sob ventilação microambiental (VMA) [resumo 34]. In: Anais da VIII Semana Científica do Departamento de Patologia - FMVZ - USP (São Paulo, Brasil). p.34.

60 Society for Laboratory Animal Science (SLAS). 1989. Committee on Training and Correct Housing of Laboratory Animals. Basel. Report On the planning and structure of animal facilities for Institutes performing Animal Experiments. pp.39-48.

61 Stoecker W.F. \& Jones J.W. 1985. Refrigeração e ar condicionado. São Paulo: Mc Graw Hill, 113 p.

62 Teixeira M.A. 1995. Ventilação microambiental para Biotérios: estudo experimental em camundongos (Mus musculus). 97f. São Paulo, SP. Dissertação (Mestrado em Patologia Experimental e Comparada) - Programa de Pós-graduação em Patologia Experimental e Comparada, Universidade de São Paulo.

63 Teixeira M.A., Chaguri L.C.A.A., Carissimi A.S., Souza N. L., Mori C.M.C., Gomes V.M.W., Poli Neto A., Nonoyama K. \& Merusse J.L.B. 2000. Perfis Hematológico e Bioquímico de ratos (Rattus norvegicus) mantidos sob sistema de ventilação microambiental. Brazilian Journal of Veterinary Research and Animal Science. 37: 342-347.

64 Teixeira M.A., Chaguri L.C.A.A., Carissimi A.S., Souza N. L., Mori C.M.C., Saldiva P.H.N., Lemos M., Macchione M., Guimarães E.T. \& Merusse J.L.B. 2000. Effect of different cage ventilation systems on nasal epittheliu and broncoalveola lavage characteristics in rats (Rattus norvegicus) [abstract A122]. In: Texas Branch American Association for Laboratory Animal Science Meeting. (Texas, U.S.A.). p.122.

65 Teixeira M.A., Chaguri L.C.A.A., Carissimi A.S., Souza N.L., Mori C.M.C., Saldiva P.H.N., Macchione M., Guimarães E.T., King M. \& Merusse J.L.B. 2000. Effect of different systems of rats (Rattus norvegicus) cage ventilation on respiratory mucus properties [abstract A-618) In: 96th International Conference of the American Thoracic Society (Toronto, Canada). American Journal of Respiratory and Critical Care Medicine. 161: A618.

66 Teixeira M.A., Chaguri L.C.A.A., Carissimi A.S., Souza N.L., Mori C.M.C., Saldiva P.H. N., Macchione M., Guimarães E.T., King M. \& Merusse J.L.B. 2005. Individually ventilated cage system improves airway integrity of rats (Rattus norvegicus). Laboratory Animals. [in press].

67 Teixeira M.A., Saldiva P.H.N., Souza N.L., Sinhorini I.L. \& Merusse J.L.B. 2001. Reduction of atmosfheric ammonia (NH3) and incidence of pulmonary lesions in mice kept in plenum chambers microenvironmental ventilation system. Scandinavian Journal of Laboratory Animal Science. 28: 145 -153.

68 Teixeira M.A., Sinhorini I.L., Souza N.L. \& Merusse J.L.B. 1999. Microenvironmetal system for laboratory animals: air distribution through plennum chambers. Animal Technology. 50: 187-194.

69 Teixeira M.A., Souza N.L. \& Merusse J.L.B. 2001. Mice (Mus domesticus domesticus) productivity in a microenvironmental ventilation system using plennum chambers. Animal Technology. 52: 233-242.

70 Torreira R. P. 1991. Salas Limpas. São Paulo: Hemus, 76 p.

71 Tu H., Diberadinis L.J. \& Lipman N.S. 1997. Determination of air distribution, exchange, velocity and leakage in three individually ventilated rodent caging systems. Contemporary Topics. 36: 69-73.

72 Turner W.A., Mcknight F.T., Jones R.B., Barth J.M., Paigen B.J., Ohman J.L. \& MacDonald M.R. 1992. Air quality evaluations of animal room facilities utilized for the production of laboratory mice. ASHRAE Transactions. 98: $262-271$.

73 Van Der Waaij A.D. \& Andreas A.H. 1971. Prevention of airborne contamination and cross-contamination in germfree mice by laminar flow. Journal of Hygiene. 69: 83-89. 
74 Weihe W.H. 1971. The significance of the physical environment for the health and state of adaptation of laboratory animals. In: National Research Council (Ed). Defining the laboratory Animal. Washington: National Academy of Sciences, pp.353-378.

75 Weihe W.H. \& Teelmann K. 1974. Temperature and air-flow patterns in air-conditioned animal laboratories. Zentralblatt für Bakteriologie, Parasitunkunde, Infektions Krankheiten und Hygiene. 159B: 298-306.

76 Wu D., Joiner G.N. \& Mcfarland A.R. 1985. A forced-air ventilation system for rodent cages. Laboratory Animal Science. 35: 499-504.

77 Yamauchi C., Obara T., Fukuyama N. \& Ueda T. 1989. Evaluation of a one-way airflow system in an animal room based on counts of airborne dust particles and bacteria and measurements of ammonia levels. Laboratory Animal Science. 31: 251-258.

78 Yoshida K., Okamoto M., Tajima M. \& Kurosawa T. 1995. Invention of forced-air-ventilated micro-isolation cage and rack system - environment within cages: Temperature and ammonia concentration. Experimental Animals. 43: 703-710.

79 Zhang Y., Christianson L.L., Riskowski G.L., Zhang B., Taylor G., Gonyou H.W. \& Harrison P.C. 1992. A survey of laboratory rat environments. ASHRAE Transactions. 98: 247-53. 